\section{Sensitivitas pp 78 tahun 2015 \\ Tentang pengupahan}

Oleh

Ibnu Affan ${ }^{1}$

\section{Abstract}

The establishment of UMP/UMK based on PP on wage is accomplished in a simple way without making survey on price. The minimum wage is determined on this PP is made by using the formula of minimum wage calculation in KHL in accordance with the productivity and economic growth. With this calculation, the rise of minimum wage could be estimated either by the employee / labor, or the entrepreneurs every year. Furthermore, it will give warranty to the entrepreneur in their entrepreneurship.

The presence of PP on wage, in fact, triggers many rejections from employee/labor because it is in contradictory with the Act of Employment which results disadvantages for employee/labor because the determination of UMK/UMP will be made without the Union of Labors but it will be decided directly by the governor without any recommendation from the regent/mayor.

Keyword : Sensitivity Pp 78 Year 2015 On Wage

\section{Abstrak}

Adapun penetapan UMP/UMK berdasarkan PP Pengupahan ini, dilakukan secara lebih sederhana tanpa melakukan survei harga. Penetapan upah minimum berdasarkan PP ini dilakukan dengan menggunakan formula perhitungan upah minimum berdasarkan $\mathrm{KHL}$ dan dengan memperhatikan produktivitas dan pertumbuhan ekonomi. Dengan cara ini kenaikan upah minimum setiap tahunnya akan dapat diprediksi baik oleh pekerja/buruh maupun oleh pengusaha dan juga memberikan kepastian kepada pihak pengusaha dalam berusaha.

Kehadiran PP Pengupahan ini ternyata mendapat penolakan dari aktivis pekerja/buruh karena dianggap bertentangan dengan UU Ketenagakerjaan dan dapat merugikan kepentingan pekerja/buruh. Karena dengan cara ini, penetapan UMP/UMK tidak lagi melibatkan

\footnotetext{
${ }^{1}$ Dosen Tetap Fakultas Hukum UISU
}

serikat pekerja/serikat buruh, akan tetapi dapat langsung ditetapkan oleh Gubernur tanpa melalui rekomendasi Depeprov atau Bupati/Walikota.

Kata Kunci: Sensitivitas PP 78 Tahun 2015, Pengupahan

\section{A. PENDAHULUAN}

1. Latar Belakang Permasalahan

Isu upah memang isu yang selalu panas sejak dulu dan hingga kini, penentuan upah minimum di daerah (Kabupaten/Kota) adalah medan perang yang paling nyata bagi pekerja/buruh. Tidak hanya merupakan isu yang paling besar dari relasi pekerja/buruh dengan pengusaha, upah juga merupakan persoalan yang paling terkait dengan pekerja/buruh di daerah khususnya pacsa kebijakan otonomi daerah. Jika dibandingkan dengan isu buruh kontrak dan outsourcing, suatu isu yang juga selalu hangat di kalangan pekerja/buruh, isu upah minimum rasanya lebih terasa gemanya sebagai isu pekerja/buruh. Karena dalam isu upah, yang dibicarakan adalah tentang sesuatu yang menjadi persoalan inti dari pekerja/buruh itu sendiri, yaitu mereka yang tidak punya apaapa selain tenaga, dan harus menjual tenaganya itu untuk hidup. Oleh karena itu, upah merupakan isu yang paling sensitif bagi pekerja/buruh, dan eksistensialnya sungguh nyata dan penting. ${ }^{2}$

Pada kenyataannya, upah juga isu yang paling sering dimanipulasi dan diputar-putar dengan analisis pakar dan data-data statistik kelas tinggi yang intinya mempersulit

2 Surya Tjandra, Yasmine MS Soraya \& Jamaludin, Advokasi Pengupahan Di Daerah (Strategi Serikat Buruh Di Era Otonomi Daerah), TURC, Jakarta, 2007, hlm. 1. 
Media Komunikasi dan Informasi Hukum dan Masyarakat

pekerja/buruh untuk memahami, apa yang sesungguhnya terjadi. Meski tidak perlu dilakukan penelitian secara mendalam, semua kita kalau mau jujur, akan menemui fakta bahwa sesungguhnya upah pekerja/buruh di Indonesia memang masih sangat rendah. Jauh dari cukup untuk memenuhi kebutuhan hidup pekerja/buruh dan keluarganya agar bisa hidup layak sebagai manusia yang bermartabat. ${ }^{3}$

Sistem pengupahan di Indonesia tidak hanya berfungsi secara ekonomi, tetapi juga memiliki fungsi kebijakan sosial, yaitu untuk melindungi pihak yang lemah dari eksploitasi pihak yang kuat. Pada hakikatnya kedudukan pekerja/buruh dengan pengusaha berada dalam posisi yang tidak seimbang dimana pengusaha berada pada posisi yang kuat dalam status sosial ekonomi sedangkan pekerja/buruh berada pada posisi lemah yang menggantungkan sumber penghasilannya dengan bekerja pada pengusaha. Sementara keduanya sama-sama manusia yang memiliki harkat dan martabat kemanusiaan (human dignity). ${ }^{4}$ Oleh karena itu campur tangan pemerintah menjadi penting dalam melahirkan kebijakan pengupahan dengan membuatkebijakan tentang upah minimum yang berfungsi sebagai jaring pengaman.

Sesungguhnya kebijakan pengupahan bukanlah merupakan kebijakan yang bisa berdiri sendiri. Kebijakan pengupahan saling terkait dengan sektor-sektor lainnya. Kebijakan pengupahan merupakan bagian yang tidak dapat dipisahkan dari kebijakan

\footnotetext{
3 Ibid., hlm. 2.

Agusmidah, Politik Hukum Dalam Hukum Ketenagakerjaan Berdasarkan Peraturan Perundang-undangan Ketenagakerjaan, Disertasi Untuk Memperoleh Gelar Doktor Dalam Ilmu Hukum Pada Sekolah Pasca Sarjana USU, Medan, 2007, hlm. 1.
}

ketenagakerjaan dalam skala makro. Sementara kebijakan ketenagakerjaan dipengaruhi oleh situasi perekonomian, kondisi ketenagakerjaan dan kondisi hubungan industrial serta pengaruh globalisasi. $^{5}$

Situasi perekonomian suatu negara sangat mempengaruhi kebijakan pengupahan yang akan dilahirkan. Penetapan upah minimum selalu didasarkan pada pertumbuhan ekonomi dan daya saing. Apabila pertumbuhan ekonomi rendah dan daya saing juga rendah, sudah barang tentu besaran upah minimum yang akan ditetapkan akan rendah pula. Sebaliknya, apabila pertumbuhan ekonomi tinggi dan data saing juga tinggi, sudah dapat dipastikan besaran upah minimum akan ditetapkan tinggi pula. Artinya pertumbuhan ekonomi dan daya saing berbanding lurus dengan besaran upah minimum yang akan ditetapkan.

Begitu pula halnya dengan kondisi ketenagakerjaan dan hubungan industrial, juga berkontribusi dalam penetapan upah minimum. Tingkat pengangguran yang tinggi dan lapangan kerja yang terbatas, membuat posisi tawar pekerja/buruh menjadi rendah. Akibatnya kualitas syarat-syarat kerja dan perlindungan kerja menjadi rendah pula, sehingga memungkinkan terjadinya perubahan hubungan kerja, awalnya pengusaha menerima pekerja/buruh dengan status sebagai pekerja tetap atau perjanjian kerja waktu tidak tertentu (PKWTT) menjadi pekerja kontrak atau perjanjian kerja waktu tertentu (PKWT). Kondisi semacam ini tentunya tidak menguntungkan

\footnotetext{
5 Tianggur Sinaga, Kebijakan Pengupahan, Disampaikan Pada Pelatihan Teknis Hakim Peradilan Umum (Karier) Tentang Perselisihan Hubungan Industrial Dalam Wilayah Hukum Pengadilan Tinggi Se-Indonesia, pada tanggal 1-13 Agustus 2005, hlm. 1.
} 
Media Komunikasi dan Informasi Hukum dan Masyarakat

bagi pekerja/buruh karena pihak pengusaha dapat kapan saja melakukan pemutusan hubungan kerja (PHK) terhadap pekerja/buruhnya secara sewenang-wenang dan menggantikannya dengan pekerja baru dengan upah yang lebih rendah.

Agar terpenuhinya kehidupan hidup layak, penghasilan pekerja/buruh harus dapat memenuhi kebutuhan fisik, non fisik dan sosial, yang meliputi makanan, sandang, perumahan, pendidikan, kesehatan, jaminan hari tua dan rekreasi. Untuk itu kebijakan pengupahan juga harus mampu mendorong pertumbuhan ekonomi dan perluasan kesempatan kerja serta meningkatkan kesejahteraan pekerja/buruh beserta keluarganya sesuai dengan perkembangan dan kemampuan dunia usaha.

Untuk peningkatan kesejahteraan pekerja/buruh dan keluarganya yang mendorong kemajuan dunia usaha serta produktivitas kerja, ketentuan mengenai pengaturan penghasilan yang layak, kebijakan pengupahan, perlindungan pengupahan, penetapan upah minimum dan pengenaan denda, Pemerintah telah mengeluarkan Peraturan Pemerintah (PP) No. 78 tentang Pengupahan atau disebut dengan PP Pengupahan.

Keluarnya PP pengupahan ini secara filosofis merupakan implementasi dari Paket Kebijakan Ekonomi Jilid IV yang diumumkan Presiden Joko Widodo pada hari Kamis, tanggal 15 Oktober 2015. Paket Kebijakan Ekonomi Jilid IV ini berfokus kepada kesejahteraan pekerja, antara lain formula upah minimum provinsi (UMP), memperluas penyaluran kredit usaha rakyat (KUR) khususnya bagi pekerja yangterkena PHK dan pemberian kredit modal kerja untuk usaha mikro, kecil dan menengah. ${ }^{6}$

Ada dua topik penting yang menjadi perhatian pemerintah dalam mendorong penguatan ekonomi masyarakat. Pertama, soal kebijakan pengupahan yang adil, sederhana dan terproyeksi. Kedua, kebijakan KUR yang lebih murah dan luas. Menurut Menteri Koordinator Bidang Perekonomian Darmin Nasution,tujuan utama dari penetapan UMP adalah membuka lapangan kerja seluas-luasnya dan juga berfungsi untuk meningkatkan kesejahteraan pekerja/buruh. ${ }^{7}$

Kebijakan itu merupakan bukti kehadiran negara dalam bentuk pemberian jaring pengaman sosial melalui kebijakan upah minimum dengan sistem formula. Secara khusus pemerintah ingin memastikan buruh tidak terjatuh ke dalam upah murah. Melalui kebijakan ini upah buruh akan naik setiap tahun dengan besaran yang terukur. Kebijakan itu juga memberi kepastian kepada pengusaha dalam berusaha. $^{8}$

Secara yuridis, keluarnya PP Pengupahan ini merupakan amanat Pasal 97 UU Ketenagakerjaan (UU No. 13 Tahun 2003 tentang Ketenagakerjaan). Pasal 97 UUKetenagakerjaanmengamanatkan agar ketentuan mengenai penghasilan yang layak, kebijakan pengupahan, kebutuhan hidup layak,

6 Darmin Nasution, Paket Kebijakan Ekonomi Jilid IV,

https://kominfo.go.id/index.php/content/detail/6215/P aket+Kebijakan+Ekonomi+Jilid+IV/0/berita, diakses pada tanggal 16 April 2016.

7 Ibid.

8 Ibid. 
Media Komunikasi dan Informasi Hukum dan Masyarakat

perlindungan upah, penetapan upah minimum,B. Pembahasan

dan pengenaan denda diatur dengan PP.

Pengaturan mengenai ketentuan tersebut di atas selama ini masih menggunakan PP No. 8 Tahun 1981 tentang Perlindungan Upah. Akan tetapi sehubungan dengan berbagai permasalahan di bidang pengupahan yang semakin kompleks, maka ketentuan tersebut disesuaikan dengan kebutuhan dan keadaaan saat ini, akhirnya pemerintah mengeluarkan PP No. 78 Tahun 2015 tentang Pengupahan yang ditetapkan pada tanggal 23 Oktober 2015 sebagai pengganti PP No. 8 Tahun 1981 tentang Perlindungan Upah.

Ternyata kehadiran PP Pengupahan ini mendapat penolakan dari aktivis pekerja/buruh, karena PP Pengupahan ini dianggap merugikan pekerja/buruh dan bertentangan dengan UU Ketenagakerjaan. Presiden Konfederasi Serikat Pekerja Indonesia (KSPI) Said lqbal bahkan mendesak para Gubernur dan Bupati/Walikota untuk menolak paket kebijakan ekonomi jilid IV dan PP Pengupahan ini. Menurut lqbal keterlibatan serikat pekerja dalam menentukan kenaikan upah merupakan sesuatu yang sangat prinsip. Negara-negara lain di seluruh dunia juga melibatkan serikat pekerja dalam menentukan kenaikan upah. Selain itu, dengan formula kenaikan upah hanya berdasarkan inflasi dan pertumbuhan ekonomi, maka upah buruh di Indonesia akan terus tertinggal bila dibandingkan dengan negara-negara lain, khususnya di ASEAN. Sebab upah dasar buruh Indonesia masih rendah. ${ }^{9}$

9 Lily Rusna Fajriah\&Rico Afrido Simanjuntak,Ini Paket Kebijakan Ekonomi Jilid IV Jokowi, http://ekbis.sindonews.com/read/1053404/33/inipaket-kebijakan-ekonomi-jilid-iv-jokowi-14449, diakses pada tanggal 16 April 2016.
Bertolak dari permasalahan tersebut di atas, beberapa hal yang menarik untuk dibahas dalam PP Pengupahan ini yang menimbulkan kontroversi antara lain adalah : 1) Penetapan upah minimum; 2) Pengaturan struktur dan skala upah; dan 3) Pembayaran upah dalam keadaan pailit.

\section{Penetapan Upah Minimum Sebelum Berlaku PP Pengupahan}

Sebelum tahun 1999, penetapan upah minimum adalah tanggung jawab pemerintah pusat, dalam hal ini Menteri Tenaga Kerja yang memutuskan upah minimum tiap-tiap daerah di seluruh Indonesia. Basisnya adalah Provinsi (daerah tingkat satu) yang disebut UMR (upah minimum regional). Sejak diberlakukannya UU No. 22 Tahun 1999 dan UU No. 25 Tahun 1999 yang kemudian diperbaiki lagi oleh UU No. 32 Tahun 2004 yang mengatur soal desentralisasi dan otonomi daerah serta perimbangan keuangan antara pusat dan daerah, maka soal upah minimum menjadi kewenangan daerah sepenuhnya. ${ }^{10}$

Sejak otonomi daerah inilah tanggung jawab penentuan upah minimum menjadi tanggung jawab sepenuhnya pemerintah daerah, dimana Pemerintah Daerah Kabupaten/Kota yang merekomendasikan dan kemudian Gubernur yang akan memutuskan. Pada masa lalu gerakan buruh terorganisir di Indonesia memfokuskan upaya-upaya lobby hampir seluruhnya di tingkat nasional dan jauh lebih sedikit pada tingkat Provinsi. Otonomi daerah telah menciptakan kesempatankesempatan baru bagi serikat buruh untuk bisa mempengaruhi hasil-hasil kebijakan perburuhan

10 Surya Tjandra, Yasmine MS Soraya \& Jamaludin, Op. Cit., hlm. 11. 
Media Komunikasi dan Informasi Hukum dan Masyarakat

langsung di daerahnya masing-masing dan untuk terlibat dalam proses pembuatan kebijakan dan peraturan secara umum. ${ }^{11}$

Hal ini dipertegas dalam UU Ketenagakerjaan yang mengatur secara eksplisit bahwa upah minimum ditetapkan oleh Gubernur dengan memperhatikan rekomendasi dari Dewan Pengupahan Provinsi dan/atau Bupati/Walikota sebagaimana diatur dalam Pasal 89 ayat (3) UUKetenagakerjaan. Untuk menetapkan besaran upah minimum di suatu daerah, Gubernur membentuk Dewan Pengupahan Provinsi (Depeprov) yang selanjutnya melakukan survei harga untuk ditetapkan sebagai nilai Kebutuhan Hidup Layak (KHL).

Survei harga dilakukan oleh Depeprov atau Dewan Pengupahan Kabupaten (Depekab)/Dewan Pengupahan Kota (Depeko) dengan membentuk tim yang keanggotaannya terdiri dari anggota Dewan Pengupahan, unsur Perguruan Tinggi/Pakar, dan dengan mengikutsertakan Badan Pusat Statistik (BPS) setempat. Keanggotaan Depeprov atau Depekab/Depeko bersifat tripartit terdiri dari unsur pemerintah, organisasi pengusaha, serikat pekerja/serikat buruh, Perguruan Tinggi dan Pakar sebagaimana diatur dalam Pasal 23 dan Pasal 40, Keputusan Presiden RI No. 107 Tahun 2004 tentang Dewan pengupahan.

Hasil survei dimaksud ditetapkan sebagai nilai $\mathrm{KHL}$ oleh Depeprov atau Depekab/Depeko, kemudian disampaikan kepada Gubernur. Berdasarkan KHL tersebut Gubernur menetapkan upah minimum dengan memperhatikan produktivitas dan pertumbuhan ekonomi. Upah minimum Provinsi yang ditetapkan Gubernur didasarkan pada nilai KHL Kabupaten/Kota terendah di Provinsi yang bersangkutan dengan mempertimbangkan produktivitas, pertumbuhan ekonomi, kondisi pasar kerja dan usaha yang paling tidak mampu (marginal).

$\mathrm{KHL}$ sendiri diatur dalam Permenakertrans RI No. 13 Tahun 2012 tentang Komponen dan Pelaksanaan Tahapan Pencapaian Kebutuhan Hidup Layak (KHL) yang menyatakan bahwa $\mathrm{KHL}$ adalah standar kebutuhan seorang pekerja/buruh lajang untuk dapat hidup layak secara fisik untuk kebutuhan 1 (satu) bulan. Upah minimum hanya berlaku bagi pekerja/buruh yang mempunyai masa kerja kurang dari satu tahun sebagaimana diatur dalam Pasal 15 ayat (2) Permenakertrans RI No. 7 Tahun 2013 tentang Upah Minimum.

Permenakertrans RI No. 13 Tahun 2012 yang merupakan aturan pelaksana dari Pasal 89 ayat (4) Undang-Undang Ketenagakerjaan, menyempurnakan Permenakertrans RI No. 17 Tahun 2005 yang mengatur komponen KHL dari 47 indikator menjadi 60 indikator yaitu : komponen makanan dan minuman 11 indikator, sandang 13 indikator, perumahan 26 indikator, pendidikan 2 indikator, kesehatan 5 indikator, transportasi 1 indikator dan rekreasi 2 indikator.

Berdasarkan Pasal 6 Permenakertrasn RI No 13 Tahun 2012, upah minimun ditetapkan dengan mempertimbangkan faktor-faktor sebagai berikut :

a. nilai $\mathrm{KHL}$ yang diperoleh dan ditetapkan dari hasil survei;

b. produktivitas makro yang merupakan hasil perbandingan antara jumlah Produk Domestik Regional Bruto (PDRB) dengan jumlah tenaga kerja pada periode yang sama;

c. pertumbuhan ekonomi merupakan pertumbuhan nilai PDRB;

11 Ibid., hlm. 12. 
Media Komunikasi dan Informasi Hukum dan Masyarakat

d. kondisi pasar kerja merupakan perbandingan jumlah kesempatan kerja dengan jumlah pencari kerja di daerah tertentu pada periode yang sama;

e. kondisi usaha yang paling tidak mampu (marginal) yang ditunjukkan oleh perkembangan keberadaan jumlah usaha marginal di daerah tertentu pada periode tertentu.

Berdasarkan nilai $\mathrm{KHL}$ yang telah disurvei oleh tim survei dan memperhatikan rekomendasi Depeprov dan/atau Bupati/Walikota selanjutnya Gubernur menetapkan Upah minimum dengan memperhatikan produktivitas dan pertumbuhan ekonomi sebagaimana diatur dalam Pasal 88 ayat (4) UU Ketenagakerjaan jo Pasal 3 Permenakertrans RI No. 7 Tahun 2013.

Skema : Mekanisme Penetapan Upah Minimum Menurut Permenakertrans RI No. 7 Tahun 2013 jo Permenakertrans RI No. 13 Tahun 2012

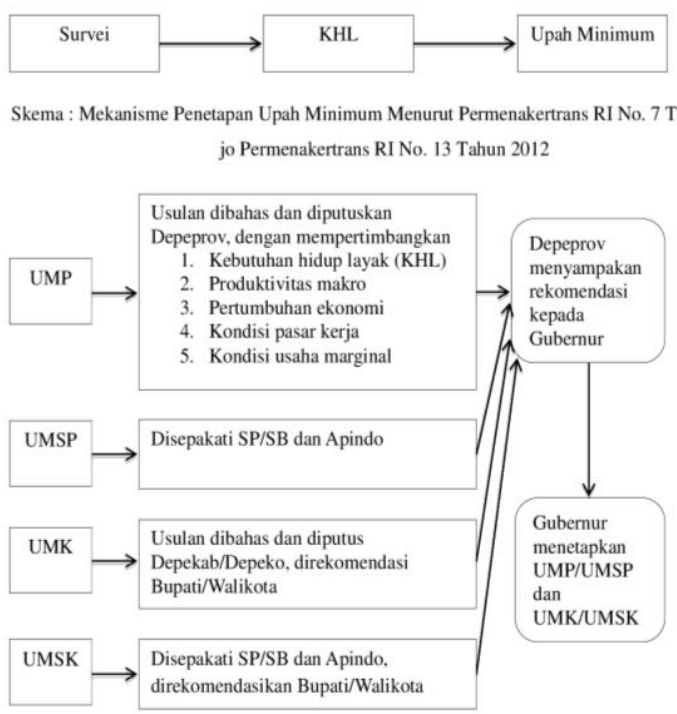

\section{Penetapan Upah Minimum Berdasarkan PP No. 78 Tahun 2015}

Terbitnya PP Pengupahan ini menuai pro dan kontra. Hal ini dikarenakan penetapan upah minimum berdasarkan PP Pengupahan adalah dengan menggunakan formula perhitungan upah minimum. Pekerja/buruh mengganggap formula perhitungan upah minimum yang hanya berdasarkan inflasi dan pertumbuhan ekonomi ini tidak berpihak pada pekerja/buruh. Sementara pemerintah mengganggap dengan formula perhitungan upah minimum maka akan ada kejelasan dan kepastian investasi bagi investor, karena biaya yang akan dikeluarkkan untuk upah pekerja/buruh sudah dapat diperhitungkan sebelumnya.

Penetapan upah minimum dengan menggunakan formula perhitungan upah minimum ini tampak lebih sederhana dan dapat diprediksi karena tidak perlu melakukan survei harga. Gubernur dapat saja langsung menetapkan UMP dan UMK tanpa melalui rekomendasi dari Depeprov dan/atau Bupati/Walikota. Survei harga baru dilaksanakan apabila dilakukan peninjauan KHL. Sementara peninjauan $\mathrm{KHL}$ berdasarkan komponen dan jenis kebutuhan hidup dilakukan dalam jangka waktu 5 (lima) tahun. Peninjauan $\mathrm{KHL}$ dilakukan oleh Menteri dengan mempertimbangan hasil kajian yang dilaksanakan oleh Dewan Pengupahan Nasional (Depenas).

Apabila dilakukan peninjauan $\mathrm{KHL}$, barulah Gubernur menetapkan UMP dan UMK dengan memperhatikan rekomendasi Depeprov dan/atau rekomendasi Bupati/Walikota. Artinya survei harga cukup dilaksanakan dalam jangka waktu 5 (lima) tahun sekali, maka dengan demikian rekomendasi dari Depeprov dan/atau 
Media Komunikasi dan Informasi Hukum dan Masyarakat

Bupati/Walikota dalam menetapkan UMP dan UMK juga cukup dilakukan dalam waktu 5 (lima) tahun sekali saja.

Sistem penetapan upah minimum menurut Pasal 43 ayat (1) PP Pengupahan adalah berdasarkan kebutuhan hidup layak dan dengan memperhatikan produktivitas dan pertumbuhan ekonomi. Oleh karena itu formula perhitungan upah minimum dilakukan sebagai berikut :

UMn $=$ UMṭ $+\{$ UMț $x($ Inflasiț+ \% $\%$ PDBț $)\}$

Keterangan :

UMn : Upah minimum yang akan ditetapkan.

UMț : Upah minimum tahun berjalan.

Inflasiț : Inflasi yang dihitung dari periode September tahun yang lalu sampai dengan periode September tahun berjalan.

^ PDBt : Pertumbuhan Produk Domestik Bruto yang dihitung dari pertumbuhan Produk Domestik Bruto yang mencakup periode kwartal III dan IV tahun sebelumnya dan periode kwartal I dan II tahun berjalan.

Inflasi : Suatu keadaan dimana harga barang secara umum mengalami kenaikan secara terus menerus atau terjadi penurunan nilai uang dalam negeri.

PDB : Jumlah produksi barang dan jasa yang dihasilkan oleh unit-unit produksi pada suatu daerah di saat tertentu.

Formula perhitungan upah minimum adalah upah minimum tahun berjalan ditambah dengan hasil perkalian antara upah minimum tahun berjalan dengan penjumlahan tingkat inflasi nasional tahun berjalan dan tingkat pertumbuhan Produk Domestik Bruto tahun berjalan.
Contoh :

UMț : :Rp. 2.000.000,Inflasiț : $5 \%$

$\wedge$ PDBt : $6 \%$

UMn $\quad=$ UMț $+\{$ UMț $x($ Inflasiț+ \% $\wedge$ PDBț $)\}$

UMn $=$ Rp. 2.000.000,- + \{Rp. 2.000.000,- x $(5 \%+6 \%)\}$

$=$ Rp. 2.000.000,- + \{Rp. 2.000.000,- x $11 \%\}=$ Rp. 2.000.000,- + Rp. 220.000,- = Rp. 2.220.000,-

Setelah UMP dan UMK ditetapkan, Gubernur dapat menetapkan UMSP dan UMSK berdasarkan hasil kesepakatan asosiasi pengusaha dengan serikat pekerja/serikat buruh pada sektor yang bersangkutan. Penetapan UMSP dan UMSK ini dilakukan setelah mendapat saran dan pertimbangan mengenai sektor unggulan dari Depeprov atau Depekab/Depeko sesuai dengan tugas dan kewenangannya. UMSP harus lebih besar dari UMP di provinsi yang bersangkutan, demikian juga dengan UMSK harus lebih besar dari UMK di kabupaten/kota yang bersangkutan. ${ }^{12}$

Berdasarkan uraian-uraian tersebut di atas, dapat dipahami bahwa penetapan upah minimum, baik sebelum maupun sesudah berlakunya PP Pengupahan tidaklah jauh berbeda. Pedomannya tetap didasarkan pada $\mathrm{KHL}$ dan dengan memperhatikan produktivitas dan pertumbuhan ekonomi. Kalaupun berbeda, hanya pada cara penetapannya saja. Sebelumnya penetapan upah minimum adalah diawali dengan penetapan KHL melalui survei harga yang dilakukan oleh tim survei dari Dewan Pengupahan. Cara ini sering menimbulkan persoalan dan perdebatan yang panjang antara anggota Dewan Pengupahan karena saling berbeda kepentingan sehingga

\footnotetext{
12 Pasal 49 PP No. 78 Tahun 2015 tentang Pengupahan.
} 
Media Komunikasi dan Informasi Hukum dan Masyarakat

dapat menyebabkan penetapan upah minimum menjadi lambat.

Adapun cara penetapan upah minimum dengan sistem formula penetapan upah minimum berdasarkan PP Pengupahan, terlihat lebih sederhana karena Gubernur dapat langsung menetapkan UMP dan UMK dengan menggunakan sistem formula penetapan upah minimum yang didasarkan pada produktivitas dan pertumbuhan ekonomi. Penetapan upah minimum dengan cara ini akan berjalan semakin cepat dan dapat diprediksi oleh pengusaha maupun pekerja/buruh. Karena indikatornya adalah inflasi dan pertumbuhan ekonomi yang dapat dilihat dari data BPS secara nasional. Syarat utamanya adalah upah minimum tahun berjalan sebagai dasar perhitungan upah minimum yang akan ditetapkan dalam formula perhitungan upah minimum, harus sudah berdasarkan KHL.

\section{Pengaturan Struktur dan Skala Upah}

Pada Pasal 14PP Pengupahan secara tegas mengatur besaran upah berdasarkan satuan waktu yang berpedoman pada struktur dan skala upah. Yang dimaksud struktur upah menurut Kepmenakertrans RI No. Kep49/Men/IV/2004 adalah susunan tingkat upah dari yang terendah sampai yang tertinggi atau dari yang tertinggi sampai yang terendah. Sedangkan skala upah adalah kisaran nilai nominal upah untuk setiap kelompok jabatan.

Mengenai struktur dan skala upah, pengusaha mempunyai kewajiban untuk menyusun struktur dan skala upah dengan memperhatikan golongan, jabatan, masa kerja, pendidikan dan kompetensi pekerja/buruh. Stuktur dan skala upah ini wajib diberitahukan kepada seluruh pekerja/buruh dan menjadi syarat yang harus dilampirkan oleh perusahaan saat permohonan pengesahan dan pembaruan peraturan perusahaan atau pendaftaran, perpanjangan dan pembaruan perjanjian kerja bersama.

Pengusaha yang tidak menyusun dan menerapkan struktur dan skala upah serta tidak memberitahukan kepada pekerja akan diberikan sanksi administratif. Sanksi administratif yang dapat dikenakan mulai dari teguran terulis, pembatasan kegiatan usaha, penghentian sementara sebagian atau seluruh alat produksi dan yang paling berat adalah pembekuan kegiatan usaha. Kewajiban menyusun dan menetapkan skala upah ini tidak ditemui dalam UU Ketenagakerjaan. Pasal 92 UUKetenagakerjaan tidak ada mewajibkan pengusaha menyusun struktur dan skala upah, apalagi memberikan sanksi. Inilah yang dianggap sebagai kalangan aktivis pekerja/buruh bertentangan dengan UUKetenagakerjaan.

Adanya kewajiban kepada pengusaha untuk menyusun dan menetapkan struktur dan skala upah ini merupakan langkah maju dalam PP Pengupahan ini. Dengan ketentuan ini, mau tidak mau pihak perusahaan harus membuat struktur dan skala upah bagi pekerja/buruhnya sehingga akan terlihat perbedaan upah antara pekerja/buruh yangtelah lama bekerja dengan pekerja/buruh yang baru bekerja, antara pekerja/buruh yang berpendidikan lebih tinggi dengan pekerja/buruh yang berpendidikan lebih rendah dan antara pekerja/buruh yang mempunyai keahlian dengan pekerja/buruh biasa.

Pengaturan struktur dan skala upah ini antara lain dimaksudkan untuk : a) mewujudkan upah yang berkeadilan; b) mendorong peningkatan produktivitas di perusahaan; c) meningkatkan kesejahteraan pekerja/buruh; dan 
Media Komunikasi dan Informasi Hukum dan Masyarakat

d) menjamin kepastian upah dan mengurangi kesenjangan antara upah terendah dan tertinggi. Oleh karena itu dapat dipandang bahwa pengaturan mengenai struktur dan skala upah dalam PP Pengupahan ini lebih baik, tajam dan terarah. Jika aturan pelaksana dari suatu UU lebih baik, tajam dan terarah menurut hemat penulis, hal itu tidaklah bertentangan dengan UU, akan tetapi manakala pengaturan dalam aturan pelaksana suatu UU lebih buruk, baru dapat dikatakan bertentangan dengan UU.

\section{Pembayaran Upah Dalam Keadaan Pailit}

Hal lain yang menarik untuk dibahas dalam PP Pengupahan ini adalah mengenai ketentuan pembayaran upah dalam keadaan kepailitan sebagaimana diatur dalam Pasal 37 PP Pengupahan. Perusahaan yang dinyatakan pailit berdasarkan putusan pengadilan maka upah dan hak-hak lainnya dari pekerja/buruh merupakan hutang yang didahulukan pembayarannya. Ketentuan ini juga secara tegas diatur dalam Pasal 95 ayat (3) UUKetenagakerjaan. Dalam kepailitan kita mengenal ada 3 (tiga) tingkatan kreditur yaitu kreditur separatis, kreditur preferen dan kreditur konkuren.

Pertama, Kreditur separatis adalah kreditur pemegang hak jaminan kebendaan, yang dapat bertindak sendiri. Golongan kreditur ini tidak terkena akibat putusan pernyataan pailit, artinya hak-hak eksekusi mereka tetap dapat dijalankan seperti tidak ada kepailitan debitur. Kreditur pemegang gadai, jaminan fidusia, hak tanggungan, dan hipotek atau hak agunan atas kebendaan lainnya merupakan karakteristik kreditur separatis.

Kedua, Kreditur preferen adalah kreditur yang memiliki hak istimewa atau hak prioritas sebagaimana diatur dalam KUHPerdata.
Berdasarkan ketentuan KUHPerdata, ada dua jenis hak istimewa, yaitu hak istimewa khusus dan hak istimewa umum. Hak istimewa khusus adalahhak yang menyangkut benda-benda tertentu, sebagaimana diatur dalam Pasal 1139 KUHPerdata sedangkan hak istimewa umum berarti menyangkut seluruh benda, sesuai dengan Pasal 1149 KUHPerdata, hak istimewa khusus di dahulukan atas hak istimewa umum.

Ketiga adalah Kreditur konkuren yaitu kreditur yang tidak termasuk dalam kreditur separatis dan kreditur preferenyaitu kreditur yang harus berbagi dengan para kreditur lainnya secara proporsional (pari passu),yaitu menurut perbandingan besarnya masing-masing tagihan, dari hasil penjualan harta kekayaan debitur yang tidak dibebani dengan hak jaminansebagaimana diatur dalam Pasal 1131 jo. Pasal 1132 KUHPerdata.

Kedudukan pekerja/buruh dalam keadaan kepailitan ini adalah berada pada tingkatan kreditur preferenyaitu kreditur yang memiliki hak istimewa, dalam hal ini hak istimewa umum sesuai ketentuan Pasal 1149 KUHPerdata yang didahulukanpembayarannya setelah pembayaran pada kreditur separatis tentunya.

Kemudian apabila pekerja/buruh jatuh pailit, maka upah dan segala pembayaran yang timbul dari hubungan kerja tidak termasuk dalam kepailitan kecuali ditetapkan lain oleh hakim dengan ketentuan tidak melebihi 25\% (dua puluh lima persen) dari upah dan segala pembayaran yang timbul dari hubungan kerja yang harus dibayarkan. Ketentuan ini diatur dalam Pasal 38 PP Pengupahan, akan tetapi tidak ada pengaturannya di dalam UUKetenagakerjaan. Pasal ini juga dianggap bertentangan dengan UU Ketenagakerjaan. 
Media Komunikasi dan Informasi Hukum dan Masyarakat

Sewajarnyalah suatu Peraturan Pemerintah (PP) yang merupakan aturan pelaksana dari suatu UU dibuat lebih bersifat teknis aplikatif yang mengatur secara mendetail pasal-pasal yang bersifat umum. Hal ini bertujuan untuk memberikan kemudahan dalam penafsiran dan implementasinya dapat dirasakan secara nyata dan konkrit di tengahtengah masyarakat.

\section{Simpulan dan Saran}

1. Simpulan

Bertolak dari hasil paparan yang telah dikemukakan di dalam tulisan ini, maka dapat ditarik kesimpulan sebagai berikut :

a) Bahwa penetapan upah minimum dengan sistem formula penetapan upah minimum merupakan penyederhanaan sistem penetapan upah agar berjalan lebih cepat, tepat dan efisien karena tanpa melalui survei harga oleh Dewan Pengupahan. Penetapan upah dengan berpedoman pada inflasi dan pertumbuhan ekonomi secara nasional akan memberikan kemudahan kepada pengusaha untuk memprediksi kenaikan upah. Hal ini tidaklah bertentangan dengan ketentuan UUKetenagakerjaan karena di dalam UUKetenagakerjaan juga tidak ada diatur mengenai survei harga. Adapun sistem survei harga hanyalah suatu tata cara penetapan upah minimum yang diatur dalam Peraturan Menteri. Sedangkan mengenai pengaturan struktur dan skala upah serta upah dalam keadaan pailit, ternyata mengandung maksud yang lebih baik dan lebih tajam dari yang telah diatur dalam ketentuan UUKetenagakerjaan, sehingga tidaklah dapat dikatakan bertentangan dengan ketentuan UU Ketenagakerjaan.

b) Bahwa oleh karena PP Pengupahan ini tidak bertentangan dengan ketentuan UUKetenagakerjaan, maka PP Pengupahan ini dengan sendirinya tidaklah merugikan kepentingan pekerja/buruh karena kenaikan upah minimum pekerja/buruh dijamin setiap tahun yang perhitungannya dilakukan dengan sistem formula perhitungan upah minimum dengan memperhatikan produktivitas dan pertumbuhan ekonomi. Bahkan PP Pengupahan ini mewajibkan pengusaha menyusun struktur dan skala upah sehingga terjamin adanya perbedaan upah antara pekerja/buruh yang telah lama bekerja dengan pekerja/buruh yang baru.Bagi pekerja/buruh yang pailit juga mendapat jaminan bahwa upah dan segala pembayaran yang timbul dalam hubungan kerja tidak termasuk dalam kepailitan kecuali ditetapkan lain oleh hakim dengan ketentuan tidak melebihi 25\% (dua puluh lima persen) dari upah dan segala pembayaran yang timbul dari hubungan kerja yang harus dibayarkan.

\section{Saran}

Bertolak dari ha-hal yang diuraikan dalam kesimpulan tersebut di atas, maka disarankan sebagai berikut :

a) Untuk memperbesar kenaikan upah minimum di masa mendatang, indikatorkomponen $\mathrm{KHL}$ perlu ditingkatkan dari 60 indikator menjadi 80 indikator yang dibuat dalam Peraturan Menteri. Penentuan KHL seharusnya bukan merupakan standar kebutuhan seorang pekerja lajang, akan tetapi standar kebutuhan untuk 
Media Komunikasi dan Informasi Hukum dan Masyarakat

pekerja/buruh yang telah berumah tangga dengan 1 (satu) orang tanggungan. Dengan cara itu, maka nilai $\mathrm{KHL}$ akan menjadi lebih besar dan dengan demikian upah minimum pekerja/buruh juga akan menjadi lebih besar pula.

b) Pengurus serikat pekerja/serikat buruh seharusnya senantiasa memonitor dan mengawasi pembuatan dan penyusunan struktur dan skala upah. Karena apabila pihak pengusaha tidak melaksanakannya dapat dikenakan sanksi administratif. Dalam hal ini, serikat pekerja/serikat buruhlah yang terlebih dahulu mengetahuinya ketimbang pihak lain. Untuk itu, keberanian dan ketegasan pengurus serikat pekerja/serikat buruh sangat diperlukan dan menentukan.

\section{DAFTAR PUSTAKA}

Agusmidah. 2001. Politik Hukum Dalam Hukum Ketenagakerjaan Berdasarkan Peraturan Perundang-undangan Ketenagakerjaan, Disertasi Untuk Memperoleh Gelar Doktor Dalam IImu Hukum Pada Sekolah Pasca Sarjana USU, Medan.

Surya Tjandra, Yasmine MS Soraya \& Jamaludin. 2007. Advokasi Pengupahan Di Daerah (Strategi Serikat Buruh Di Era Otonomi Daerah). Jakarta : TURC.

Kitab Undang-Undang Hukum Perdata (Burgerlijk Wetboek voor Indonesie). Stb. Tahun 1847 Nomor 23.

Undang-Undang Nomor13 Tahun 2003 tentang Ketenagakerjaan. Lembaran Negara RI Tahun 2003 Nomor 39.

Undang-Undang Nomor 32 Tahun 2004 tentang Pemerintah Daerah. Lembaran Negara RI Tahun 2004 Nomor 125.

Undang-Undang Nomor 37 Tahun 2004 tentang Kepailitan dan Penundaan Kewajiban Pembayaran Utang. Lembaran Negara RI Tahun 2004 Nomor 131.
Peraturan Pemerintah Nomor 78 Tahun 2015 tentang Pengupahan. Lembaran Negara RI Tahun 2015 Nomor 237.

Keputusan Presiden RI No. 107 Tahun 2004 tentang Dewan pengupahan.

Peraturan Menteri Tenaga Kerja dan Transmigrasi RI Nomor 13 Tahun 2012 tentang Komponen dan Pelaksanaan Tahapan Pencapaian Kebutuhan Hidup Layak. Berita Negara RI Tahun 2012 Nomor 707.

Peraturan Menteri Tenaga Kerja dan Transmigrasi RI Nomor 7 Tahun 2013 tentang Upah Minimum. Berita Negara RI Tahun 2013 Nomor 1239.

Peraturan Menteri Tenaga Kerja dan Transmigrasi RI Nomor : Per03/Men///2005 tentang Tata Cara Pengusulan Keanggotaan Dewan Pengupahan Nasional.

Keputusan Menteri Tenaga Kerja dan Transmigrasi RI Nomor Kep.49/Men/IV/2004 tentang Ketentuan Struktur dan Skala Upah.

Tianggur Sinaga. 2005. Kebijakan Pengupahan, Disampaikan Pada Pelatihan Teknis Hakim Peradilan Umum (Karier) Tentang Perselisihan Hubungan Industrial Dalam Wilayah Hukum Pengadilan Tinggi Se-Indonesia, pada tanggal 1-13 Agustus 2005.

Darmin Nasution, Paket Kebijakan Ekonomi Jilid IV,

https://kominfo.go.id/index.php/content/ detail/6215/Paket+Kebijakan+Ekonomi+Jili $\mathrm{d}+\mathrm{IV} / \mathrm{O} /$ berita, diakses pada tanggal 16 April 2016.

Lily Rusna Fajriah\&Rico Afrido Simanjuntak, Ini Paket Kebijakan Ekonomi Jilid IV Jokowi, http://ekbis.sindonews.com/read/10534 04/33/ini-paket-kebijakan-ekonomi-jilidiv-jokowi-14449, diakses pada tanggal 16 April 2016. 